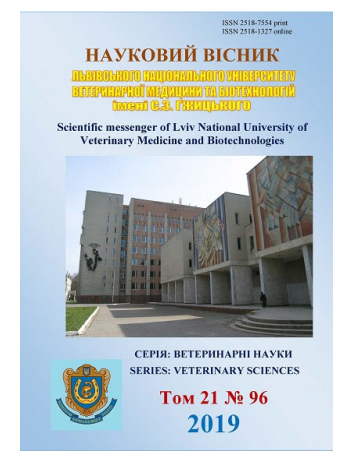

\author{
Науковий вісник Дьвівського національного університету \\ ветеринарної медицини та біотехнологій імені С.3. Гжицького. \\ Серія: Ветеринарні науки \\ Scientific Messenger of Lviv National University \\ of Veterinary Medicine and Biotechnologies. \\ Series: Veterinary sciences
}

\title{
The influence of different amounts of zinc citrate on blood biochemical indices and productivity of rabbit organism
}

\author{
Ya.V. Lesyk, M.M. Khomyn, I.V. Luchka, N.O. Bosanevich \\ Institute of Animal Biology NAAS, Lviv, Ukraine
}

Article info

Received 04.10.2019

Received in revised form 06.11 .2019

Accepted 07.11.2019

Institute of Animal Biology NAAS, V. Stus Str., 38, Lviv, 79034, Ukraine.

Tel.: +38-068-503-46-25

E-mail:lesykyv@gmail.com
Lesyk, Ya.V., Khomyn, M.M., Luchka, I.V., \& Bosanevich, N.O. (2019). The influence of different amounts of zinc citrate on blood biochemical indices and productivity of rabbit organism. Scientific Messenger of Lviv National University of Veterinary Medicine and Biotechnologies. Series: Veterinary sciences, 21(96), 65-70. doi: 10.32718/nvlvet9611

Deficiency of micro- and macronutrients in the organism of young rabbits causes disorders of metabolism and decreased productivity. Inclusion of essential micronutrients made by nanotechnology to the rabbit diet can eliminate this problem. Therefore, the purpose of our research was to investigate the influence of different amounts of zinc citrate in combination with cobalt and chromium citrates on the biochemical processes in the organism and the productivity of rabbits from 62 to 86 days of age. Researches were performed on rabbits 40 days of age, weighing 1.2-1.4 kg. The animals of the experimental groups were fed with fodder ration of the control group and during the day were fed with cobalt citrate in the amount of $40 \mu \mathrm{g} \mathrm{Co} / \mathrm{kg}$ of body weight, chromium citrate - $40 \mathrm{mcg} \mathrm{Cr} / \mathrm{kg}$ of body weight and zinc citrate, calculated respectively in I, II and III of experimental groups $0.25 ; 0.50$ and $0.75 \mathrm{mg} \mathrm{Zn} / \mathrm{kg}$ of body weight. In the preparatory period - on the 10th day and in the experimental on the 12th, 24th and 36th days of drinking the supplements in 4 animals from the group blood samples were taken for biochemical researches. Body weight gain was also determined by weighing. It was found that in the blood of animals of the first experimental group on the 12th day of drinking mineral additives increased the cholesterol content on 28.8\%, on 24 th day - decrease by $39.1 \%$ and increase - creatinine by $11.6 \%$, and on 36th day -increase in blood of total protein on $12.3 \%$, increase of alkaline phosphatase activity by $23.0 \%$, creatinine content by $15.5 \%$ and average daily growth by $9.4 \%$. A similar additive containing zinc citrate of $0.50 \mathrm{mg} \mathrm{Zn} / \mathrm{kg}$ of body weight in the blood of rabbits of the second experimental group increased the activity of ACAT by 12 and 24 days, respectively, by 37.3 and $22.1 \%$, respectively, and reduced their cholesterol content by 33.9 and $63.1 \%$ compared to the control. Whereas in the same group the growth of ALT activity was noted by $23.7 \%$, and the average daily increase was higher than the control indicator by $7.9 \% 36$ days of the research in comparison with the control group. The high content of zinc citrate in the mineral supplement $(0.75 \mathrm{mg} \mathrm{Zn} / \mathrm{kg})$ in the blood of rabbits of the third experimental group contributed to the increase of the total protein concentration in all periods of the research, AST activity increased by $26.1 \%$ on the 24 th day, AAT by $34.9 \%$ and the content of triacylglycerols and cholesterol was decreased, while on the 36th day the AAT activity increased by $20.3 \%$, under these conditions, the average daily weight gain of rabbits was the highest and amounted to $38.4 \mathrm{~g}$, which was $12.9 \%$ higher than the control. Therefore, the additive in the content of citrates of Co and $\mathrm{Cr}$ in the amount of $40 \mu \mathrm{g} / \mathrm{kg}$ of body weight and Zn citrate in the amount of $0.75 \mathrm{mg}$ $\mathrm{Zn} / \mathrm{kg}$ of body weight contributed to the improvement of metabolic processes and increase of growth indices, which may indicate the dose-dependent influence of the additives used in the rabbit young body.

Key words: rabbits, blood, nano Co citrate, nano Cr citrate, nano Zn citrate, biochemical parameters, weight gain.

\section{Вплив різної кількості цинку цитрату на біохімічні показники крові та продуктивність організму кролів}

\author{
Я.В. Лесик, М.М. Хомин, І.В. Лучка, Н.О. Босаневич
}


Дефіцит мікро- та макроелементів в організмі молодняку кролів спричиняє порушення метаболізму та зниження продуктивності. Включення до раціону кролів есенціальних мікроелементів, виготовлених методом нанотехнологій, може усунути ию проблему. Тому метою нашого дослідження було дослідити вплив різних кількостей цитрату циинку в поєднанні з ичтратами кобальту і хрому на біохімічні процеси в організмі та продуктивність кролів з 62 до 86 доби життя. Дослідження проводили на кролях породи Термонська, відібраних у 40-добовому віці за приниипом аналогів, масою тіла 1,2-1,4 кг. Тваринам дослідних груп згодовували корми раціону контрольної групи і впродовж доби випоювали кобальту ичитрату в кількості 40 мкг Со/кг маси тіла, хрому циитрату - 40 мкг Cr/кг маси тіла та ичинку циитрату, з розрахунку відповідно у I, II $i$ III дослідних групах 0,25; 0,50 i 0,75 мг Zn/кг маси тіла. Дослід тривав 46 діб, в тому числі підготовчий період - 10 діб, а дослідний - 36 діб. У підготовчому періоді на 10 добу $i$ в дослідному на 62, 74 та 86 доби життя (12, 24 та 36 доби випоювання добавок) у 4 тварин з групи відбирали зразки крові з крайової вушної вени для біохімічних досліджень. На початку дослідження та в завершальний період визначали прирости маси тіла шляхом зважування. Дослідженнями встановлено, щзо випоювання циттратів хрому $і$ кобальту в поєднанні з найменшою досліджуваною кількістю ичнку циттрату (0,25 мг Zn/кг) у крові кролів I дослідної групи на 12 добу сприяло підвищенню вмісту холестеролу на 28,8\%, на 24 добу - зменшенню на 39,1\% та підвищенню креатиніну на 11,6\%, а на 36 добу - збільшенню у крові загального протеїну на 12,3\%, зростанню активності лужної фосфатази на 23,0\%, вмісту креатиніну на 15,5\% та середньодобових приростів на 9,4\%. Аналогічна добавка з вмістом цинку цүитрату 0,50 мг Zn/кг маси тіла у крові кролів II дослідної групи підвищувала активність АсАТ на 12 та 24 доби відповідно на 37,3 і 22,1\% та зменшувала вмісту холестеролу на 33,9 та 63,1\% порівняно з контролем. Тоді як у цієї ж групи відзначено зростання активності АлАТ на 23,7\%, а середньодобові прирості були вищими від контрольного показника на 7,9\% на 36 добу дослідження порівняно з контрольною групою. Високий вміст изинку изитрату у мінеральній добавці (0,75 мг Zn/кг) у крові кролів III дослідної групи сприяв підвищенню концентрацї загального протеїну в усі періоди досліджень, на 24 добу підвищувалась активність АсАТ на 26,1\%, АлАТ на 34,9\% та зменшувався вміст триацилгліцеролів і холестеролу, на 36 добу дослідження зростала активність АлАТ на 20,3\%, за цих умов середньодобові прирости маси тіла кроленят були найвищими і становили 38,4 2, щуо на 12,9\% було більшим від контролю. Отже, мінеральна добавка у складі Со ичитрату і Сг циттрату та Zn цитрату у кількості 0,75 мг Zn/кг маси тіла сприяла поліпшенню обмінних процесів та підвищенню показників росту, щуо може свідчити про дозозалежний вплив застосованих добавок в організмі молодняку кролів.

Ключові слова: кролики, кров, нано кобальт цүитрат, нано хром цүитрат, нано цүинк циттрат, біохімічні показники, маса тіла.

\section{Ветуп}

Відомо, що мінеральні речовини в організмі становлять невелику частину його маси, однак вони відіграють важливу роль як каталізатори у процесах протеїнового, ліпідного, вуглеводного i мінерального обмінів, активують функції гормонів, вітамінів та ензимів (Taylor, 1996; Sapozhnikov \& Gordova 2013; Davyidova et al., 2015; Medvid et al., 2017).

Зокрема, Хром бере участь у процесах регуляції рівня глюкози в крові ссавців, підтримуючи його оптимальну концентрацію, позитивно впливає на активність інсуліну. Крім цього, він регулює синтез жирних кислот і знижує вміст холестеролу й триацилгліцеролів у крові, а також сприяє виведенню 3 організму токсинів і солей важких металів (Pohorielov et al., 2010; Byistrova et al., 2013). Біологічна роль Кобальту полягає у його присутності в молекулі ціанкобаламіну - вітаміну $\mathrm{B}_{12}$, який відіграє роль у процеcax кровотворення (Young, 1985), він є також коферментом низки життєвоважливих ензимів - рибонуклеозидтрифосфатредуктази, метилтрансферази, метилмалоніл-СоА-мутази, аденілатциклази та регулює метаболізм вуглеводного, протеїнового та ліпідного обмінів (Malard et al., 2007). Цинк, крім участі у диханні й нуклеїновому обміні, підвищує діяльність статевих залоз, впливає на формування скелета плода. При нестачі цинку зменшується вміст РНК і знижується синтез протеїну (Chan et al., 1998). У швидкоростучого молодняку тварин частіше спостерігаються дефіцитні стани за нестачі мінеральних речовин.

Про можливість застосування хелатів біогенних мікроелементів, виготовлених методом нанотехнології, як високоактивних сполук у тваринництві та ветеринарній медицині свідчить низка досліджень
(Kosinov \& Kaplunenko, 2009; Borysevych et al., 2010). 3'ясовано вплив органічних сполук мікроелементів у різних кількостях, зокрема $\mathrm{Cr}, \mathrm{Se}, \mathrm{Zn}, \mathrm{Cu}, \mathrm{Mg}$ та I на обмінні процеси в організмі щурів, кролів, корів та бджіл. Встановлено вищу біологічну ефективність додавання нанокарбоксилатів біогенних мікроелементів, ніж їх мінеральних солей, до раціону тварин, що вказує на необхідність перегляду нормування як для кожного елементу, так і для їхнього комплексного застосування (Chekman et al., 2012; Sobolev et al., 2017; 2018). Так, додавання комплексу нанокарбоксилатів біогенних мікроелементів у кількості, що становить лише 10-15\% від добової норми, стимулює активність антиоксидантної системи, підвищує резистентність, поліпшує протеїновий, мінеральний та вітамінний профіль крові, підсилює дезінтоксикаційні процеси в організмі тварин порівняно з нормованою кількістю мінеральних солей вказаних мікроелементів (Lesyk et al., 2014; Dolaychuk et al., 2015; Khomyn et al., 2016). Однак вплив комплексного застосування цитратів мікроелементів та різного їх співвідношення у раціоні на біохімічні процеси в організмі молодняку кролів ще недостатньо вивчені.

Мета роботи. Дослідити вплив різних кількостей цитрату цинку в поєднанні 3 цитратами кобальту i хрому на біохімічні процеси та продуктивність організму кролів з 62 до 86 доби життя.

\section{Матеріал і методи досліджень}

Дослідження проводили на молодняку кролів породи Термонська в умовах віварію Інституту біології тварин НААН. Кролів для дослідження відбирали у віці 40 діб за принципом аналогів, масою тіла 1,21,4 кг, розділяли на чотири групи (контрольну і три 
дослідних), по 4 тварин (2 самці і 2 самиці) у кожній. Тварин утримували в приміщеннях 3 регульованим мікрокліматом та освітленням у сітчастих клітках розміром $50 \times 120 \times 30$ см, відповідно до сучасних ветеринарно-санітарних норм. Кролям контрольної групи згодовували без обмеження збалансований гранульований комбікорм, з вільним доступом до води згідно 3 нормами (Bohdanov \& Kandyby, 2012). Тваринам дослідних груп згодовували корми раціону контрольної групи і впродовж доби випоювали мінеральну добавку у складі нано кобальту цитрату в кількості 40 мкг Со/кг маси тіла, нано хрому цитрату в кількості 40 мкг $\mathrm{Cr} /$ кг маси тіла та нано цинку цитрату, з розрахунку відповідно у I, II і ІІІ дослідних груп 0,25; 0,50 і 0,75 мг Zn/кг маси тіла. Дослід тривав 46 діб, в тому числі підготовчий період - 10 діб, а дослідний 36 діб. У підготовчому періоді на 10 добу і в дослідному на 62, 74 та 86 добу життя $(12,24$ та 36 доби випоювання добавок) у 4 тварин 3 групи відбирали зразки крові з крайової вушної вени для біохімічних досліджень. У крові визначали вміст загального протеїну, креатиніну, Кальцію, неорганічного фосфору, сечовини, холестеролу, триацилгліцеролів, активність лужної фосфатази, аспартатамінотрансферази (АсАТ) і аланінамінотрансферази (АлАТ) за допомогою наборів Humman (Німеччина) на біохімічному аналізаторі “Humalyzer 2000” відповідно до інструкцій виробників. На початку дослідження та у завершальний період визначали прирости маси тіла за методикою, описаною у довіднику (Vlizlo et al., 2012). Отримані числові дані обробляли за допомогою стандартного пакету статистичних програм Microsoft EXCEL.

\section{Результати та їх обговорення}

Як показали дослідження, у підготовчий період на 50 добу життя біохімічні показники крові кролів перебували на рівні фізіологічної норми, а їхні величини не мали вірогідних відмінностей між контрольною та дослідними групами (табл. 1). Натомість у результаті застосування впродовж дослідного періоду органічних мінеральних добавок отримано дані, що свідчать про дозозалежний стимулювальний вплив досліджуваних цитратів мікроелементів на окремі біохімічні показники організму кролів.

\section{Таблиця 1}

Біохімічні показники крові молодняку кролів за випоювання цитратів хрому і кобальту та різної кількості цитрату цинку, $(\mathrm{M} \pm \mathrm{m}, \mathrm{n}=4)$

\begin{tabular}{|c|c|c|c|c|c|}
\hline \multirow{3}{*}{ Показник } & \multirow{3}{*}{$\begin{array}{l}\text { Группа } \\
\text { тварин }\end{array}$} & \multicolumn{4}{|c|}{ Періоди дослідження } \\
\hline & & \multirow{2}{*}{$\begin{array}{l}\text { підготовчий, } \\
50 \text { доба життя }\end{array}$} & \multicolumn{3}{|c|}{ дослідний, доба життя/доба випоювання добавок } \\
\hline & & & $62 / 12$ & $74 / 24$ & $86 / 36$ \\
\hline \multirow{4}{*}{$\begin{array}{c}\text { Загальний протеїн, } \\
\text { г/л }\end{array}$} & $\mathrm{K}$ & $52,3 \pm 2,16$ & $54,2 \pm 2,85$ & $56,7 \pm 2,92$ & $56,9 \pm 2,15$ \\
\hline & Д-І & $51,6 \pm 1,33$ & $53,0 \pm 2,39$ & $57,9 \pm 3,98$ & $63,9 \pm 1,83^{*}$ \\
\hline & Д-II & $49,8 \pm 2,03$ & $52,3 \pm 0,72$ & $57,2 \pm 0,76$ & $53,8 \pm 1,70$ \\
\hline & Д-III & $53,5 \pm 1,07$ & $64,5 \pm 1,25^{*}$ & $61,2 \pm 3,98$ & $65,2 \pm 2,98$ \\
\hline \multirow{4}{*}{ АсАТ, од/л } & $\mathrm{K}$ & $23,3 \pm 1,16$ & $20,1 \pm 2,49$ & $22,6 \pm 1,20$ & $24,8 \pm 2,12$ \\
\hline & Д-І & $23,6 \pm 1,15$ & $28,2 \pm 2,78$ & $21,8 \pm 1,31$ & $28,6 \pm 2,01$ \\
\hline & Д-ІІ & $21,1 \pm 0,25$ & $27,6 \pm 1,60^{*}$ & $27,6 \pm 1,55^{*}$ & $26,5 \pm 1,53$ \\
\hline & Д-ІІІІ & $24,5 \pm 1,13$ & $23,1 \pm 1,88$ & $28,5 \pm 0,30 * *$ & $27,4 \pm 2,44$ \\
\hline \multirow{4}{*}{ АлАТ, од/л } & $\mathrm{K}$ & $43,0 \pm 2,92$ & $44,0 \pm 2,54$ & $41,0 \pm 3,81$ & $44,3 \pm 1,54$ \\
\hline & Д-I & $35,0 \pm 1,83$ & $47,6 \pm 5,18$ & $51,8 \pm 5,23$ & $50,1 \pm 5,59$ \\
\hline & Д-II & $32,3 \pm 3,55$ & $48,4 \pm 1,11$ & $48,7 \pm 3,26$ & $54,8 \pm 2,93^{*}$ \\
\hline & Д-ІІІ & $38,5 \pm 1,88$ & $48,0 \pm 4,19$ & $55,3 \pm 3,67 *$ & $53,3 \pm 2,12^{*}$ \\
\hline \multirow{4}{*}{$\begin{array}{c}\text { Лужна фосфатаза, } \\
\text { од/л }\end{array}$} & $\mathrm{K}$ & $438,2 \pm 20,9$ & $407,3 \pm 33,7$ & $379,2 \pm 63,0$ & $312,9 \pm 12,9$ \\
\hline & Д-І & $422,5 \pm 23,5$ & $357,2 \pm 39,5$ & $369,6 \pm 24,2$ & $384,9 \pm 11,8^{* *}$ \\
\hline & Д-II & $392,6 \pm 24,5$ & $331,2 \pm 38,2$ & $354,5 \pm 46,0$ & $374,9 \pm 26,9$ \\
\hline & Д-III & $388,2 \pm 34,2$ & $407,2 \pm 37,7$ & $347,5 \pm 29,7$ & $339,2 \pm 18,4$ \\
\hline \multirow{4}{*}{ Сечовина, ммоль/л, } & $\mathrm{K}$ & $7,57 \pm 0,28$ & $5,20 \pm 0,88$ & $5,40 \pm 0,33$ & $5,45 \pm 0,40$ \\
\hline & Д-І & $7,46 \pm 0,44$ & $4,68 \pm 0,52$ & $5,13 \pm 0,57$ & $5,23 \pm 0,18$ \\
\hline & Д-II & $6,61 \pm 0,32$ & $4,78 \pm 0,32$ & $4,90 \pm 0,10$ & $6,23 \pm 0,87$ \\
\hline & Д-III & $7,41 \pm 0,55$ & $4,95 \pm 0,61$ & $5,33 \pm 0,34$ & $3,93 \pm 0,52$ \\
\hline \multirow{4}{*}{$\begin{array}{c}\text { Холестерол, } \\
\text { ммоль/л }\end{array}$} & $\mathrm{K}$ & $1,24 \pm 0,80$ & $1,18 \pm 0,07$ & $1,79 \pm 0,10$ & $1,55 \pm 0,36$ \\
\hline & Д-І & $1,16 \pm 0,32$ & $1,52 \pm 0,10^{*}$ & $1,09 \pm 0,11 * *$ & $1,49 \pm 0,06$ \\
\hline & Д-II & $1,18 \pm 0,12$ & $0,78 \pm 0,11^{*}$ & $0,66 \pm 0,09 * * *$ & $1,22 \pm 0,18$ \\
\hline & Д-III & $1,22 \pm 0,40$ & $1,07 \pm 0,27$ & $0,85 \pm 0,13 * *$ & $1,12 \pm 0,23$ \\
\hline \multirow{4}{*}{$\begin{array}{c}\text { Триацилглі- } \\
\text { цероли, ммоль/л }\end{array}$} & $\mathrm{K}$ & $0,99 \pm 0,04$ & $0,92 \pm 0,16$ & $0,80 \pm 0,11$ & $0,98 \pm 0,41$ \\
\hline & Д-І & $0,96 \pm 0,22$ & $1,22 \pm 0,17$ & $1,31 \pm 0,25$ & $0,69 \pm 0,05$ \\
\hline & Д-ІІІ & $0,88 \pm 0,64$ & $0,79 \pm 0,11$ & $0,95 \pm 0,07$ & $0,66 \pm 0,11$ \\
\hline & Д-III & $0,79 \pm 0,20$ & $0,89 \pm 0,20$ & $0,93 \pm 0,13$ & $0,76 \pm 0,18$ \\
\hline \multirow{4}{*}{$\begin{array}{l}\text { Креатинін, } \\
\text { мкмоль/л }\end{array}$} & $\mathrm{K}$ & $80,8 \pm 2,11$ & $111,0 \pm 3,48$ & $110,3 \pm 2,12$ & $106,3 \pm 3,41$ \\
\hline & Д-І & $79,9 \pm 1,30$ & $114,3 \pm 4,18$ & $123,1 \pm 2,08 * *$ & $122,8 \pm 2,67 * *$ \\
\hline & Д-II & $83,5 \pm 3,42$ & $98,0 \pm 4,07$ & $105,7 \pm 1,06$ & $114,1 \pm 2,40$ \\
\hline & Д-ІІІ & $79,1 \pm 2.12$ & $108.6 \pm 3.28$ & $110.6 \pm 3.11$ & $103.7 \pm 1.50$ \\
\hline
\end{tabular}

Примітка: *-P $<0,05,{ }^{* *}-\mathrm{P}<0,01,{ }^{* * *}-\mathrm{P}<0,001-$ вірогідна різниця порівняно з показниками контрольної групи 
Так, комплексна мінеральна добавка 3 низьким вмістом цинку цитрату (0,25 мг $\mathrm{Zn} / к г)$ сприяла підвищенню у крові кролів I дослідної групи на 12 добу iї випоювання вмісту холестеролу на $28,8 \%$ ( $<<0,05)$, на 24 добу - зниженню його кількості на 39,1\% $(\mathrm{P}<0,05)$ та підвищенню вмісту креатиніну на $11,6 \%$ $(\mathrm{P}<0,01)$, а на 36 добу - зростанню у крові загального протеїну на $12,3 \%$ ( $<<0,05)$, активності лужної фосфатази - на 23,0\% (P < 0,01) та вмісту креатиніну на $15,5 \%$ ( $<<0,01)$ порівняно з контрольною групою.

Мінеральна добавка з вмістом цинку цитрату 0,50 мг Zn/кг маси тіла спричиняла вірогідне зростання активності АсAT у крові кролів II дослідної групи на 12 та 24 добу іiї випоювання відповідно на 37,3 та $22,1 \%$, а АлАТ на 36 добу - на 23,7\% (P < 0,05). Варто зазначити, що при цьому зменшувався вмісту холестеролу, особливо на 12 і 24 добу випоювання, відповідно на 33,9 та 63,1\% та невірогідно - триацилгліцеролів впродовж дослідження. Очевидно, застосування вказаної кількості цинку цитрату в більшій мірі сприяє підвищенню метаболізму в їхньому організмі, особливо процесів, що задіяні зі зменшенням вмісту продуктів ПОЛ.

Мінеральна добавка з розрахунку цинку цитрату 0,75 мг Zn/кг маси тіла сприяла збільшенню вмісту загального протеїну в крові кролів III дослідної групи протягом досліджень, особливо на 12 добу іiї випоювання, величина даного показника була на 19,0\%
$(\mathrm{P}<0,05)$ вищою за аналогічний у тварин контрольної групи. Крім цього, виявлено зростання активності амінотрансфераз у всі періоди досліджень порівняно 3 контролем. Так, активність АсАТ зростала на 26,1\% ( $>0,01)$ на 24 добу, а АлАТ на 24 та 36 добу застосування добавки відповідно на 34,9 та $20,3 \%$ $(\mathrm{P}<0,05)$. За цих умов зменшувався вміст у крові тварин триацилгліцеролів, а також холестеролу, особливо на 24 добу на 52,5\% (P < 0,01). Варто зазначити, що незважаючи на вірогідні зміни, величини досліджуваних біохімічних показників перебували в межах фізіологічної норми для молодняку даного виду тварин.

Дослідженнями встановлено, що мінеральні добавки, випоювані кролям після відлучення, не мали суттєвого впливу на вміст Кальцію і неорганічного фосфору в їхній крові і були в межах фізіологічної норми (табл. 2). Не виявлено певних закономірностей у величині значень показників між групами. Варто зазначити, що кальцієво-фосфорне співвідношення було вищим в кролів у підготовчий період порівняно 3 дослідними, що, можливо, обумовлено віковим чинником. Проте на 36 добу випоювання мінеральних добавок тваринам I, II та особливо III дослідних груп було незначно вищим порівняно з контрольним показником, що може свідчити про певний вплив органічної добавки на досліджувані макроелементи.

\section{Таблиця 2}

Вміст Кальцію і неорганічного фосфору та їхнє співвідношення у крові молодняку кролів за випоювання цитратів хрому і кобальту та різної кількості цитрату цинку, $(\mathrm{M} \pm \mathrm{m}, \mathrm{n}=4)$

\begin{tabular}{|c|c|c|c|c|c|}
\hline \multirow{3}{*}{ Показник } & \multirow{3}{*}{$\begin{array}{l}\text { Группа } \\
\text { тварин }\end{array}$} & \multicolumn{4}{|c|}{ Періоди дослідження } \\
\hline & & \multirow{2}{*}{$\begin{array}{l}\text { Підготовчий, } \\
50 \text { доба життя }\end{array}$} & \multicolumn{3}{|c|}{ дослідний, доба життя/доба випоювання добавок } \\
\hline & & & $62 / 12$ & $74 / 24$ & $86 / 36$ \\
\hline \multirow{4}{*}{$\begin{array}{c}\text { Загальний кальцій, } \\
\text { ммол/л }\end{array}$} & $\mathrm{K}$ & $3,26 \pm 0,133$ & $2,57 \pm 0,145$ & $2,63 \pm 0,146$ & $2,78 \pm 0,103$ \\
\hline & Д-І & $3,33 \pm 0,218$ & $2,60 \pm 0,187$ & $2,45 \pm 0,222$ & $2,98 \pm 0,246$ \\
\hline & Д-II & $3,56 \pm 0,033$ & $2,45 \pm 0,119$ & $2,50 \pm 0,204$ & $2,83 \pm 0,125$ \\
\hline & Д-III & $3,26 \pm 0,120$ & $2,75 \pm 0,150$ & $2,55 \pm 0,155$ & $2,73 \pm 0,085$ \\
\hline \multirow{4}{*}{$\begin{array}{c}\text { Неорганічний фосфор, } \\
\text { ммол/л, }\end{array}$} & $\mathrm{K}$ & $1,46 \pm 0,120$ & $1,95 \pm 0,279$ & $1,87 \pm 0,319$ & $2,15 \pm 0,126$ \\
\hline & Д-І & $1,20 \pm 0,152$ & $1,92 \pm 0,311$ & $2,00 \pm 0,163$ & $2,08 \pm 0,165$ \\
\hline & Д-ІІ & $1,46 \pm 0,185$ & $1,93 \pm 0,295$ & $2,15 \pm 0,155$ & $2,13 \pm 0,118$ \\
\hline & Д-III & $1,26 \pm 0,133$ & $1,90 \pm 0,234$ & $2,03 \pm 0,205$ & $1,83 \pm 0,144$ \\
\hline \multirow{4}{*}{$\mathrm{Ca}: \mathrm{P}$} & $\mathrm{K}$ & $2,23: 1$ & $1,31: 1$ & $1,40: 1$ & $1,29: 1$ \\
\hline & Д-І & $2,77: 1$ & $1,35: 1$ & $1,22: 1$ & $1,43: 1$ \\
\hline & Д-II & $2,43: 1$ & $1,26: 1$ & $1,16: 1$ & $1,32: 1$ \\
\hline & Д-III & $2,58: 1$ & $1,44: 1$ & $1,25: 1$ & $1,49: 1$ \\
\hline
\end{tabular}

Мінеральні добавки позитивно впливали на прирости маси тіла кролів. Так, на 36 добу випоювання мінеральної добавки з меншим вмістом цинку цитрату прирости маси тіла у кролів на 86 добу життя були вищими на 9,5\% порівняно 3 їніми ровесниками у контрольній групі (табл. 3). У тварин II дослідної групи, які отримували мінеральну добавку з цинком цитрату в кількості 0,50 мг Zn/кг маси тіла, прирости маси тіла тварин були вищими на $8,1 \%$, а у кролів III дослідної групи, які отримували мінеральну добавку 3 цинком цитрату в кількості 0,75 мг Zn/кг маси тіла вищими на 12,9\%. Відповідно і середньодобові при- рости маси тіла останніх були вищими відповідно на 3,2; 2,7 та 4,4 г порівняно $з$ контролем.

Отже, застосування органічної мінеральної добавки молодняку кролів дослідних груп сприяло стимулюючому впливу на біохімічні процеси та продуктивність їх організму. Так, найвищі результати отримано за умов використання мінеральної добавки з високим вмістом цинку цитрату, що позначилося збільшенням у крові вмісту загального протеїну, активності АлАТ та зниженням - сечовини, холестеролу та триацилголіцеролів. При цьому кальцієво-фосфорне співвідношення у них було найвище серед їхніх ровесників 3 
інших груп, а середньодобові прирости маси тіла були на 12,9\% вищими від аналогічного показника тварин контрольної групи.

Застосована добавка з найменшим вмістом цитрату цинку протягом 36 діб сприяла зростанню у крові тварин активності лужної фосфатази, збільшенню вмісту креатиніну, загального протеїну, кальцієвофосфорного співвідношення і в результаті - збільшенню середньодобових приростів маси тіла на 9,4\%.

\section{Таблиця 3}

Ріст організму молодняку кролів за випоювання цитратів хрому і кобальту та різної кількості цитрату цинку, $(\mathrm{M} \pm \mathrm{m}, \mathrm{n}=4)$

\begin{tabular}{ccccccc}
\hline \multirow{2}{*}{ Група } & \multicolumn{2}{c}{ Підготовчий період, 50 доба життя } & \multicolumn{3}{c}{ Дослідний період, 86 доба життя } \\
\cline { 2 - 6 } тварин & Маса тіла, г & $\begin{array}{c}\text { Приріст маси } \\
\text { тіла, г }\end{array}$ & СДП, г & Маса тіла, г & $\begin{array}{c}\text { Приріст маси } \\
\text { тіла, г }\end{array}$ & СДП, г \\
\hline К & $1431,2 \pm 126,6$ & $1371,2 \pm 126,6$ & $27,4 \pm 2,53$ & $2655,0 \pm 122,3$ & $1223,8 \pm 49,8$ & $34,0 \pm 1,37$ \\
& 100 & 100 & 100 & 100 & 100 & 100 \\
Д-І & $1458,7 \pm 47,3$ & $1398,7 \pm 47,3$ & $27,9 \pm 0,94$ & $2798,7 \pm 59,0$ & $1340,0 \pm 83,1$ & $37,2 \pm 2,30$ \\
\% до К & 101,9 & 102,0 & 101,8 & 105,4 & 109,5 & 109,4 \\
Д-ІІ & $1385,0 \pm 96,3$ & $1325,0 \pm 96,3$ & $26,5 \pm 1,92$ & $2707,5 \pm 39,0$ & $1322,5 \pm 67,9$ & $36,7 \pm 1,87$ \\
\% до К & 96,7 & 96,6 & 96,7 & 102,0 & 108,1 & 107,9 \\
Д-ІІІ & $1373,7 \pm 45,3$ & $1313,7 \pm 45,3$ & $26,3 \pm 0,90$ & $2756,2 \pm 108,1$ & $1382,5 \pm 94,2$ & $38,4 \pm 2,26$ \\
\% до К & 95,9 & 95,8 & 96,0 & 103,8 & 113,0 & 112,9 \\
\hline
\end{tabular}

Варто зазначити, що мінеральна добавка з вмістом цинку цитрату у кількості 0,50 мг Zn/кг маси тіла тварини мала менш виражені зміни біохімічних показників крові кролів, кальцієво-фосфорне співвідношення хоча і було вищим, ніж у тварин контрольної групи, однак нижчим, ніж у тварин I та III дослідних груп, а середньодобові прирости маси тіла кролів були вищими від тварин з контрольної групи лише на $7,9 \%$.

\section{Висновки}

1. Випоювання органічних мікроелементів та цинку цитрату 3 розрахунку 0,25 мг $\mathrm{Zn} /$ кг маси тіла у крові кролів на 12 добу іiї випоювання сприяло збільшенню вмісту холестеролу на 28,8\%, на 24 добу зменшенню на 39,1\% та збільшенню вмісту креатиніну на $11,6 \%$, а на 36 добу - підвищенню загального протеїну на $12,3 \%$, креатиніну на $15,5 \%$, активності лужної фосфатази на 23,0\% та середньодобових приростів на $9,4 \%$.

2. Аналогічна добавка 3 вмістом цинку цитрату 0,50 мг Zn/кг маси тіла відзначилася зростанням активності АсАТ у крові кролів на 12 та 24 доби дослідження відповідно на 37,3 і 22,1\% та зниженням вмісту холестеролу на 33,9 та $63,1 \%$, на 36 добу спостерігалися зростання активності АлАТ на 23,7\% та середньодобові прирости на 7,9\%.

3. Застосування цинку цитрату $(0,75$ мг $\mathrm{Zn} /$ кг $)$ сприяло зростанню рівня загального протеїну у крові кролів в усі періоди досліджень, на 24 добу зростала активність АсАТ на 26,1\%, АлАТ на 34,9\% та зменшувався вміст триацилгліцеролів і холестеролу, на 36 добу випоювання зростала активність АлАТ на 20,3\%, середньодобові прирости маси тіла кроленят були найвищими і становили 38,4 г, що на $12,9 \%$ були більшим від контролю.

Перспективи подальших досліджень. Дослідження будуть скеровані на розширення кількості мінераль- них сполук біогенних елементів для раціону кролів після відлучення.

\section{References}

Bohdanov, H.O., \& Kandyby, V.M. (2012). Normy i ratsiony povnotsinnoi hodivli vysokoproduktyvnoi rohatoi khudoby: dovidnyk-posibnyk. K.: Ahrar. nauka (in Ukrainian).

Borysevych, V.B., Kaplunenko, V.H., \& Kosinov, M.V. (2010). Nanomaterialy v biolohii. Osnovy nanoveterynarii. Posib. Dlia stud. Ahrar. Zakl. Osvity III-IV rivniv akredytatsii za spets. "Vet. medytsyna" ta veterynarno-metodychnykh spetsialistiv. K.: VD "Avitsena" (in Ukrainian).

Byistrova, N.A., Konoplya, A.I., \& Shushkevich, D.L. (2013). Rol mikroelementov V biohimicheskih protsessah: Uchebnoe posobie. Kursk (in Russian).

Chan, S., Gerson, B., \& Subramaniam, S. (1998). The role of copper, molybdenum, selenium, and zinc in nutrition and health. Clin. Lab. Med., 18(4), 673-685. https://www.ncbi.nlm.nih.gov/pubmed/9891606.

Chekman, I.S., Ulberg, Z.R., \& Malanchuk, V.O. (2012). Nanoscience, nanobiology, nanopharmaceutics. Kyiv, Poligraphplus (in Ukrainian).

Davyidova, N.O., Notova, S.V., \& Kvan, O.V. (2015). Vliyanie elementnogo statusa organizma na kognitivnyie funktsii. Mikroelementy $\mathrm{v}$ meditsine, 3, 3-9 (in Russian).

Dolaychuk, O.P., Fedoruk, R.S., \& Kropyvka, S.J. (2015). Physiological reactivity and antioxidant defense system of the animal organism induced by Germanium, Chromium, and Selenium "nanoaquacitrates". Agriculture science and practice, 2(2), 50-52 (in Ukrainian).

Khomyn, M.M., Kovalchuk, I.I., Khrabko, M.I., Oleksiuk, N.P., \& Romaniv, L.I. (2016). Vplyv nanoakvakhelatnykh rozchyniv $\mathrm{Cr}$, Se, I, Co i $\mathrm{Zn}$ na orhanizm koriv i biolohichnu tsinnist moloka. Nau- 
kovyi visnyk LNUVMBT imeni S.Z. Hzhytskoho. Ceriia "Silskohospodarski nauky", 18, 1(65), 162-168. https://nvlvet.com.ua/index.php/agriculture/article/vie w/3521 (in Ukrainian).

Kosinov, M.V., \& Kaplunenko, V.G. (2009). Method of obtaining metal carboxylates. Nanotechnology for obtaining metal carboxylates. Patent of Ukraine for Utility Model No. 38391. IPC (2006): C07C 51/41, C07F 5/00, C07F 15/00, C07C 53/126 (2008.01), C07C 53/10 (2008.01), A23L 1/00, B82B 3/00. Publ. 2009, bull. no. 1/2009 (in Ukrainian).

Lesyk, Ya.V., Fedoruk, R.S., Khomyn, M.M., \& Kropyvka, S.Y. (2014). Aktyvnist antyoksydantnoi systemy orhanizmu krolematok u period vypoiuvannia sulfatu natriiu, khlorydu i tsytratu khromu. Visnyk Sumskoho natsionalnoho ahrarnoho universytetu. Seriia "Veterynarna medytsyna", 1(34), 217-221 (in Ukrainian).

Malard, V., Berenguer, F., Pratt, O. et al. (2007). Global gene expression profiling in human lung cells exposed to cobalt. BMS Genomics, 8, 147-164. doi: 10.1186/1471-2164-8-147.

Medvid, S.M., Hunchak, A.V., Hutyi, B.V., \& Ratych, I.B. (2017). Perspektyvy ratsionalnoho zabezpechennia kurchat-broileriv mineralnymy rechovynamy. Naukovyi visnyk LNUVMBT imeni S.Z. Gzhytskoho, 19(79), 127-134 doi: 10.15421/nvlvet7925.
Pohorielov, M.V., Bumeister, V.I., Tkach, H.F. ta in. (2010). Makro- ta mikroelementy (obmin, patolohiia ta metody vyznachennia). Sumy: Vyd-vo SumDU (in Ukrainian).

Sapozhnikov, S.P., \& Gordova, V.S. (2013). Microelements. Medicine, 14, 3-13 (in Russian).

Sobolev, A., Gutyj, B., Grynevych, N., Bilkevych, V., \& Mashkin, Y. (2017). Enrichment of meat products with selenium by its introduction to mixed feed compounds for birds. Regulatory Mechanisms in Biosystems, 8(3), 417-422. doi: 10.15421/021764.

Sobolev, O., Gutyj, B., Petryshak, R., Pivtorak, J., Kovalskyi, Y., Naumyuk, A., Petryshak, O., Semchuk, I., Mateusz, V., Shcherbatyy, A., \& Semeniv, B. (2018). Biological role of selenium in the organism of animals and humans. Ukrainian Journal of Ecology, 8(1), 654-665. doi: 10.15421/2017_263.

Taylor, A. (1996). Detection and monitoring of disorders of essential trace elements. Ann. Clin. Biochem, 33, 486-510. doi: 10.1177/000456329603300603.

Vlizlo, V.I., Fedoruk, R.S., Ratych, I.B. ta in (2012). Laboratorni metody doslidzhen $\mathrm{u}$ biolohii, tvarynnytstvi ta veterynarnii medytsyni [Tekst]: dovidnyk. Lviv: SPOLOM (in Ukrainian).

Young, R.S. (1985). Cobalt. Biochem. essent. ultratrace elem, 133-147. 